\title{
Subhuman Primate Pregnancy Complicated by Streptozotocin-Induced Diabetes Mellitus
}

\author{
Daniel H. Mintz, Ronald A. Chez, and Donald L. Hutchinson \\ From the Department of Medicine, University of Miami School of \\ Medicine, Miami, Florida 33152 and the Department of Obstetrics \\ and Gynecology, University of Pittsburgh, School of Medicine, \\ Pittsburgh, Pennsylvania 15213
}

A B S T R A C T Polydipsia, polyuria, polyphagia, and glucosuria followed the administration of streptozotocin to 6 nonpregnant and 15 pregnant monkeys (Macaca mulatta) in the first trimester of pregnancy. The diabetogenic action of the drug was also reflected in an induced but variable deterioration in maternal intravenous glucose tolerance and a marked attenuation of maternal plasma insulin responsiveness to intravenous glycemic stimuli. The products of conception were examined in 29 pregnancies. The neonates and the placentas of the streptozotocin-treated pregnant animals were significantly heavier than average for the period of gestation, polyhydramnios was consistently present, and there was an increase in the incidence of third trimester stillbirths.

The fetal and maternal plasma glucose, insulin, and growth hormone concentrations were examined after the intravascular administration of glucose or a solution of mixed amino acids to the fetus in the third trimester. The neonatal plasma responses to similar insulinogenic stimuli were also examined.

Fetal and neonatal base line plasma insulin concentrations were significantly elevated compared to those of the controls. The administration of intravascular glucose to the fetus, mother, or neonate was associated with a prompt 2-to 5-fold increase in fetal or neonatal plasma insulin concentrations. These findings contrast to the unresponsiveness of the pancreatic islet tissue we reported in normal subhuman primate pregnancy.

The intravascular infusion of a relatively low concentration of mixed amino acids $(2 \mathrm{mg} / \mathrm{min})$ to the con-

These studies were presented in part at the American Society for Clinical Investigation Annual Meeting, Atlantic City, N. J., May 1971.

Dr. Chez's present address is Pregnancy Research Branch, National Institute of Child Health and Human Development, National Institutes of Health, Bethesda, Md. 20014.

Received for publication 28 September 1971 and in revised form 4 October 1971. ceptii from the streptozotocin-treated pregnancies was associated with an elevation in fetal and neonatal plasma insulin levels, whereas normal monkey fetuses and neonates required a 10 -fold greater concentration of amino acids in the infusate for similar responses. The induced hyperaminoacidemia or hyperglycemia did not consistently alter plasma growth hormone concentrations in the conceptii from normal or streptozotocin-treated pregnancies.

These data provide evidence that maternal glucose intolerance during pregnancy is associated with enhanced fetal and neonatal pancreatic islet cell responsiveness to glucose and mixed amino acids. Although the specific mechanism(s) that alters both the sensitivity and responsiveness of the normal pancreatic fetal islet to insulinogenic stimuli remains unclear, the data do indicate that insulin-dependent maternal hyperglycemia and hyperaminoacidemia, separately or in combination could contribute to the fetal hyperinsulinemia of pregnancies complicated by diabetes mellitus. Moreover, the overall experiences with these streptozotocin-treated animals suggest that a subhuman primate model may be available to examine directly the antenatal pathophysiology of abnormal carbohydrate metabolism.

\section{INTRODUCTION}

Maternal, fetal, and neonatal carbohydrate insulin and growth hormone metabolism in normal monkeys (Macaca mulatta) during the third trimester of pregnancy were detailed in previous studies from our laboratory (1-3). During the last trimester fetal plasma insulin concentrations were not altered by exogenously induced acute fetal hyperglycemia. These observations obtained from normal pregnancies provide a basis for comparing fetal and neonatal beta islet cell function in pregnancies complicated by maternal hyperglycemia. 
The hypothesis, primarily advanced by Pedersen, Bojsen-Moller, and Poulsen (4), is that maternal hyperglycemia is associated with enhanced fetal and neonatal pancreatic islet cell function. Although considerable indirect evidence can be marshalled to support this concept (5-10), one of the problems in substantiating directly the validity of the Pedersen hypothesis, has been the absence of an experimental primate model in which to examine antenatal responses. Recently, a pancreatic beta cell cytotoxic agent, streptozotocin, has become available for experimental use in primates (11) and other species (12-14). The experiments reported in this paper provide data related to the effects of streptozotocin-induced alteration in maternal metabolism on fetal and neonatal carbohydrate-insulin metabolism and growth and development.

\section{METHODS}

Surgical techniques. Female rhesus monkeys (Macaca mulatta), in the breeding colony of the University of Pittsburgh for a minimum of 18 months, were used. Accurate menstrual histories and breeding dates permitted precise calculation of gestational age. An intravenous glucose tolerance test was performed immediately before the administration of the investigative drug, streptozotocin (U9889, Lot No. 9164-VDV-132, courtesy W. Dulin, Upjohn Co., Kalamazoo, Mich.). After a $16 \mathrm{hr}$ fast and medication with intramuscular phencyclidine hydrochloride $(1 \mathrm{mg} / \mathrm{kg}$, Sernylan, Parke, Davis \& Co., Detroit, Mich.), a cannula was inserted into the inferior vena cava via the saphenous vein with the animal in the left lateral decubitus position. After waiting $40 \mathrm{~min}, 0.5 \mathrm{~g}$ glucose $/ \mathrm{kg}$ body weight was injected intı dvenously in $1 \mathrm{~min} ; 2.0-\mathrm{ml}$ blood samples were removed before, and at $5,10,15,20$, and $30 \mathrm{~min}$ after injection for determination of the plasma concentrations of glucose and insulin. Streptozotocin $(40,45$, or $48 \mathrm{mg} / \mathrm{kg})$, freshly prepared in $\mathrm{pH} 4.3$ citrate buffer, was then administered intravenously.

Each animal was housed in individual metabolic cages which permitted the measurement of $24 \mathrm{hr}$ urinary output and water intake. Fresh urine samples were tested for glucose and ketone bodies (Clinitest, Ketostix, Ames Co., Elkhart, Ind.) three times a day. The daily number of biscuits consumed (Purina Monkey Chow 25, Ralston $\mathrm{Pu}$ rina Co., St. Louis, Mo.) and weekly body weights were also recorded. In the majority of animals an intravenous glucose tolerance test, performed as above, was repeated at 28-day intervals during gestation.

Fetal experiments were performed from 139 to 151 days gestation. The gestation period for this monkey colony is approximately 164 days. The specific aspects of the medication, anesthesia, and surgical technique and the postoperative care of the newborns have been previously reported (1-3). Briefly, under phencyclidine and halothane anesthesia, abdominal laparotomy was performed. After an incision through the myometrium, decidua, and chorion, an interplacental fetal artery or vein was isolated and then cannulated with a silicone rubber $\mathrm{T}$-tube. This $\mathrm{T}$-tube permits both continuous flow through the vessel and sequential sampling of fetal blood while the fetus remains in the intact amniotic sac. Maternal blood was sampled through a cannula placed into the inferior vena cava from insertion at a saphenous vein. Maternal blood samples were approximately $3.0 \mathrm{ml}$ in volume; fetal blood samples did not exceed $1.2 \mathrm{ml}$. These portions of blood were replaced with equal volumes of dilute heparin-normal saline $(5 \mathrm{U} / \mathrm{ml})$.

At the end of the intrauterine experiment, the amniotic fluid volume was measured and the fetus delivered and weighed. These newborns and those spontaneously delivered vaginally were transferred to a temperature-controlled, humidified, oxygenated environment. Studies were performed, via the cannulated umbilical vein, on fasted nonanesthetized neonates within $8 \mathrm{hr}$. of life.

Endocrine stimulation studies. The fetal and simultaneous maternal plasma glucose, immunoreactive insulin, and growth hormone responses to single glucose injections, and combined glucose injections and infusions, were examined. In four experiments, glucose injection alone $(2 \mathrm{ml}$ of $12.5 \%$ glucose in Ringer's lactate) or followed by a glucose infusion $(20 \mathrm{mg} / 0.1 \mathrm{ml}$ per $\mathrm{min}$ for $15 \mathrm{~min}$ or $50 \mathrm{mg} / 0.25$ $\mathrm{ml}$ per $\mathrm{min}$ for $10 \mathrm{~min}$ ) was administered intravascularly directly to the fetus. In three experiments, $250 \mathrm{mg}$ glucose was injected intravenously into the cannulated umbilical vein of the newborn. Blood samples were withdrawn simultaneously from the fetal and maternal or neonatal circulations before, and 2, 5, 10,20, 40, and $60 \mathrm{~min}$ after the initial injection. In two additional experiments, glucose $(0.5$ $\mathrm{g} / \mathrm{kg}$ body weight) was injected intravenously to the mother, and fetal and maternal blood samples were obtained simultaneously before, and $5,10,15,20$, and $30 \mathrm{~min}$ after the glucose injection.

An infusion of a mixture of nine amino acids (arginine, lysine, phenylalanine, leucine, methionine, valine, histidine, isoleucine, and threonine) (15) at rates of either $2 \mathrm{mg} / 0.1$ $\mathrm{ml}$ per $\min$ or $20 \mathrm{mg} / 0.2 \mathrm{ml}$ per $\min$ for $30 \mathrm{~min}$ was intravenously administered to six fetuses and neonates from streptozotocin-treated and seven conceptii of normal control mothers. Blood samples were obtained from the cannulated interplacental vessels or the umbilical vein before, and 15,30, 45, and $60 \mathrm{~min}$ after the start of the infusion.

The plasma was separated immediately and analyzed in duplicate for glucose by a glucose oxidase method (Glucostat, Worthington Biochemical Corp., Freehold, N. J.). Fetal and maternal plasma insulin and fetal growth hormone concentrations were measured by a modification (16) of the charcoal-coated radioimmunoassay method of Herbert, Kam-Seng, Gottlieb, and Bleicher (17). The specificity, sensitivity, and reproductivity of the insulin and growth hormone assays were previously reported $(1,2$, 18). Student's $t$ test was used to calculate the statistical significance of the differences of the means. In those instances in which the assumption of identical variance was not met, Satterthwaite's formula for degrees of freedom was applied (19).

\section{RESULTS}

29 gestations were examined. Of this, 15 animals were administered streptozotocin between 54 and 65 days gestation; 8 of these animals had a second pregnancy which was also monitored. Six other animals received streptozotocin before conception. Normal pregnant animals in the colony during the period of this study simultaneously served as untreated controls. Persistent increases in water intake and urinary output and glucosuria when it did occur were observed within 2 days 
TABLE I

The Maternal Responses to the Administration of Streptozotocin

\begin{tabular}{|c|c|c|c|c|c|c|c|c|c|c|c|c|}
\hline \multirow[b]{3}{*}{ No. } & \multicolumn{3}{|c|}{ Amount of streptozotocin } & \multirow{3}{*}{$\begin{array}{l}\text { Aver- } \\
\text { age } \\
\text { fluid } \\
\text { intake }\end{array}$} & \multirow{3}{*}{$\begin{array}{c}\text { Aver- } \\
\text { age } \\
\text { urine } \\
\text { output }\end{array}$} & \multirow{3}{*}{$\begin{array}{c}\text { Aver- } \\
\text { age } \\
\text { glu- } \\
\text { cos- } \\
\text { uria }\end{array}$} & \multirow{3}{*}{$\begin{array}{l}\text { Length } \\
\text { of } \\
\text { gesta- } \\
\text { tion }\end{array}$} & \multirow{2}{*}{\multicolumn{2}{|c|}{ Maternal wt gain }} & \multirow{3}{*}{$\begin{array}{l}\text { Fetal } \\
\text { weight }\end{array}$} & \multirow{3}{*}{$\begin{array}{l}\text { Amniotic } \\
\text { fluid }\end{array}$} & \multirow{3}{*}{$\begin{array}{c}\text { Placenta } \\
\text { wt }\end{array}$} \\
\hline & & Before & During & & & & & & & & & \\
\hline & & nancy & nancy & & & & & Gross & Net* & & & \\
\hline & $\begin{array}{c}m g / \\
k g\end{array}$ & & & $\begin{array}{c}m l / \\
24 h r\end{array}$ & $\begin{array}{c}m l / \\
24 h r\end{array}$ & $\begin{array}{l}\mathrm{g} / 100 \\
\mathrm{ml} \mathrm{per} \\
12 \mathrm{hr}\end{array}$ & days & \multicolumn{2}{|c|}{$k g$} & $k g$ & $m l$ & $k g$ \\
\hline 255 & 45 & & + & 707 & 421 & $\frac{3}{4}-1$ & 141 & 2.3 & 1.5 & 0.51 & 133 & 0.18 \\
\hline \multirow[t]{2}{*}{350} & 40 & & + & 575 & 243 & 0 & 141 & 1.6 & 0.9 & 0.42 & 135 & 0.15 \\
\hline & & + & & 957 & 535 & 0 & 140 & 1.8 & 1.0 & 0.42 & 214 & 0.15 \\
\hline \multirow[t]{2}{*}{309} & 48 & & + & 1238 & 651 & 0 & 148 & 1.6 & 0.9 & 0.43 & 121 & 0.13 \\
\hline & & + & & 1668 & 1121 & 0 & 141 & 0.5 & -0.1 & 0.38 & 114 & 0.14 \\
\hline 219 & 45 & & + & 1421 & 1083 & $1-2$ & 139 & 0.3 & -0.5 & 0.40 & 242 & 0.18 \\
\hline 446 & 48 & & + & 781 & 616 & $\frac{3}{4}-1$ & 141 & 0.9 & 0.1 & 0.48 & 186 & 0.15 \\
\hline 35 & 45 & + & & 737 & 683 & $\frac{3}{4}-1$ & 140 & 1.6 & 0.6 & 0.49 & 325 & 0.21 \\
\hline \multirow[t]{2}{*}{216} & 45 & & + & 1417 & 1148 & $\frac{3}{4}-1$ & 146 & -0.7 & 一 & 0.46 & - & - \\
\hline & & + & & 1498 & 1099 & $\frac{3}{4}-1$ & 120 & 2.2 & $1.6 \ddagger$ & 0.25 & 187 & 0.16 \\
\hline \multirow[t]{2}{*}{404} & 48 & & + & 1394 & 860 & $\frac{3}{4}-1$ & 155 & 1.3 & - & 0.65 & - & 0.19 \\
\hline & & + & & 1853 & 1416 & $\frac{3}{4}-1$ & 139 & 0.1 & -1.0 & 0.40 & 305 & 0.17 \\
\hline \multirow[t]{2}{*}{335} & 48 & & + & 535 & 337 & 0 & 144 & 0.7 & - & 0.45 & - & - \\
\hline & & + & & 547 & 336 & 0 & 138 & 2.3 & 1.7 & 0.37 & 124 & 0.11 \\
\hline \multirow[t]{2}{*}{48} & 45 & & + & 777 & 623 & $\frac{1}{2}$ & 141 & 1.6 & 0.8 & 0.45 & 192 & 0.15 \\
\hline & & + & & 1597 & 1217 & $\frac{1}{2}$ & 137 & 1.4 & 0.3 & 0.41 & 458 & 0.14 \\
\hline \multirow[t]{2}{*}{352} & 45 & & + & 669 & 356 & 0 & 138 & 2.3 & 1.4 & 0.40 & 209 & 0.16 \\
\hline & & + & & 667 & 359 & 0 & 141 & 1.5 & 0.8 & 0.39 & 157 & 0.14 \\
\hline 33 & 45 & + & & 425 & 205 & 0 & 142 & 1.5 & - & 0.44 & - & 0.12 \\
\hline \multirow[t]{2}{*}{358} & 45 & & + & 792 & 412 & $\frac{1}{2}$ & 117 & 0.7 & $-\ddagger$ & 0.22 & - & - \\
\hline & & + & & 1654 & 1223 & $\frac{1}{2}$ & 130 & -0.2 & $-\ddagger$ & 0.30 & - & - \\
\hline 272 & 45 & & + & 846 & 732 & $\frac{1}{2}$ & 117 & -1.0 & $-\ddagger$ & 0.23 & - & 0.08 \\
\hline 46 & 45 & & + & 410 & 256 & 0 & 96 & 0.5 & $-\ddagger$ & - & - & 0.07 \\
\hline 377 & 45 & & + & 744 & 554 & $\frac{3}{4}-1$ & 142 & 0.1 & $-\ddagger$ & 0.43 & - & 0.14 \\
\hline 212 & 40 & + & & 1658 & 1090 & $\frac{3}{4}-1$ & 138 & 2.5 & 1.7 & 0.49 & 137 & 0.18 \\
\hline 405 & 45 & & + & 1216 & 926 & $\frac{3}{4}-1$ & 144 & 0.5 & $-\ddagger$ & 0.32 & - & - \\
\hline 481 & 45 & + & & 1290 & 802 & 0 & 139 & 0.9 & 0.3 & 0.38 & 105 & 0.09 \\
\hline 53 & 45 & + & & 1213 & 850 & $\frac{3}{4}-1$ & 131 & 0.9 & $-\ddagger$ & 0.36 & - & - \\
\hline 419 & 45 & + & & 1478 & 951 & $\frac{1}{2}$ & 140 & 0.7 & -0.2 & 0.44 & 180 & 0.15 \\
\hline \multicolumn{2}{|c|}{ Mean§ } & & & 942 & 657 & & & 1.0 & 0.8 & 0.42 & 178.5 & 0.15 \\
\hline \multicolumn{2}{|c|}{ SEM } & & & 87 & 68 & & & 0.22 & 0.21 & 0.02 & 21.46 & 1.01 \\
\hline \multicolumn{13}{|c|}{ Controls\| } \\
\hline \multicolumn{2}{|c|}{ Mean } & & & 331 & 369 & & & 0.8 & 0.3 & T & 89 & ๆ \\
\hline $\mathrm{SE}$ & & & & 17 & 47 & & & 0.10 & 0.09 & & 10 & \\
\hline
\end{tabular}

* Gross maternal weight change less fetal weight, placental weight, and amniotic fluid volume when available.

$\ddagger$ Intrauterine fetal death.

$\S$ Values from first pregnancy only; eight second pregancies excluded.

\| 20 concurrent normal control pregnancies.

I The mean and the SEM at various durations of gestation are demonstrated in Fig. 1.

after the injection of streptozotocin to the female. The presence and magnitude of these changes, however, were variable from one animals to another and did not correlate with the amount of streptozotocin injected (Table I). The streptozotocin-treated group when compared to the control animals manifested polydipsia and polyuria $\left(P<0.01\right.$, respectively). Glucosuria varying from $\frac{1}{2}$ to 1 $\mathrm{g} / 100 \mathrm{ml}$ was present in $62 \%$ of the treated animals. Ketonuria was intermittently present in one animal (216) during the last 2 months of the first pregnancy. Insulin $(0.25 \mathrm{U} / \mathrm{kg} \mathrm{SQ}$ Iletin, Eli Lilly and Co., Indianapolis, Ind.) was used to treat this isolated ketonuria. The affected animals required a threefold increase in daily biscuit consumption to maintain or gain weight 
during gestation. With this polyphagia, the mean net maternal weight change, obtained by subtracting the placental and fetal weights and amniotic fluid volume from the gross maternal weight changes in the streptozotocin-treated animals was greater than that in the normal pregnancies $(P<0.01)$. However, in $38 \%$ of the streptozotocin-treated group it was not possible to obtain this determination because of vaginal delivery with loss of amniotic fluid, or cannibalization of the placenta, or both.

Table II provides a sequential tabulation of the maternal fasting plasma glucose and immunoreactive insulin concentrations, and the plasma glucose disappearance half times (obtained from a semilog plot of the plasma glucose concentrations at $10,15,20$, and $30 \mathrm{~min}$ ) and maximum increment from base line plasma insulin concentrations observed during intravenous glucose tolerance tests. Data obtained at gestational age 55-65 days before streptozotocin administration and then at three subsequent tests at monthly intervals until delivery are presented. In the six animals which received streptozotocin before conception, the data at gestational age 55-65 days were obtained during a previous normal pregnancy, before the administration of the drug.

The maternal fasting plasma glucose levels in the control and the test animals before streptozotocin injection were identical Subsequently, the mean fasting plasma glucose concentration observed at each monthly inter-

TABLE II

Intravenous Glucose Tolerance Tests during Pregnancy

\begin{tabular}{|c|c|c|c|c|c|c|c|c|c|c|c|c|c|c|c|c|}
\hline \multirow[b]{3}{*}{ No. } & \multicolumn{16}{|c|}{ Gestation days } \\
\hline & \multicolumn{4}{|c|}{$55-65$} & \multicolumn{4}{|c|}{$85-95$} & \multicolumn{4}{|c|}{$115-125$} & \multicolumn{4}{|c|}{$140-155$} \\
\hline & FBS* & $T \frac{1}{2} *$ & FIRI* & $\begin{array}{c}\text { Max } \\
\Delta \mathrm{IRI}{ }^{*}\end{array}$ & FBS & $T \frac{1}{2}$ & FIRI & $\begin{array}{c}\text { Max } \\
\Delta \text { IRI }\end{array}$ & FBS & $T_{\frac{1}{2}}$ & FIRI & $\begin{array}{c}\operatorname{Max} \\
\Delta \mathrm{IRI}\end{array}$ & FBS & $T \frac{1}{2}$ & FIRI & $\begin{array}{r}\text { Max } \\
\Delta \text { IRI }\end{array}$ \\
\hline & \multicolumn{2}{|l|}{$\begin{array}{c}m \mathrm{mg} / \\
100 \mathrm{ml}\end{array}$} & \multicolumn{2}{|c|}{$n g / m l$} & \multicolumn{2}{|l|}{$\begin{array}{c}m g / \\
100 m l\end{array}$} & \multicolumn{2}{|c|}{$n g / m l$} & \multicolumn{2}{|l|}{$\begin{array}{c}m \mathrm{mg} / \\
100 \mathrm{ml}\end{array}$} & \multicolumn{2}{|c|}{$n g / m l$} & $\begin{array}{c}m g / \\
100 m l\end{array}$ & & \multicolumn{2}{|c|}{$n g / m l$} \\
\hline 255 & 25 & 9.2 & 5.3 & 20.0 & 40 & 31.0 & 3.6 & 1.3 & 48 & 23.0 & 2.0 & 1.3 & 39 & 70.0 & 1.2 & 0.5 \\
\hline 350 & 22 & 12.5 & 3.6 & 12.7 & 61 & 22.0 & 5.8 & 3.3 & 35 & 20.0 & 3.6 & 4.6 & 70 & 26.0 & 1.9 & 1.5 \\
\hline 309 & 25 & 9.5 & 2.2 & 15.5 & 46 & 17.0 & 5.2 & 8.6 & - & - & - & - & 56 & 20.0 & 3.3 & 0.4 \\
\hline 219 & 45 & 14.5 & 4.4 & 22.2 & 201 & 35.5 & 3.1 & 0.8 & - & 一 & - & - & 80 & 39.5 & 1.2 & 0.7 \\
\hline 446 & 46 & 13.0 & 4.7 & 24.3 & 28 & 18.8 & 2.0 & 5.8 & 41 & 27.8 & 1.7 & 1.5 & 60 & 26.5 & 2.1 & 1.2 \\
\hline 35 & 31 & 12.3 & 2.1 & 38.9 & 36 & 18.0 & 1.0 & 9.3 & 58 & 25.0 & 4.8 & 4.0 & 63 & 20.0 & 3.7 & 2.6 \\
\hline 216 & 26 & 9.0 & 3.4 & 34.6 & 81 & 36.0 & 3.9 & 0.9 & 277 & 43.0 & 2.5 & 0.2 & 325 & 52.0 & 1.6 & 0.6 \\
\hline 404 & 36 & 9.5 & 2.4 & 20.1 & 57 & 36.0 & 2.4 & 0.6 & 172 & 40.0 & 0.8 & 0.7 & 164 & 31.0 & 2.4 & 0.8 \\
\hline 335 & 36 & 13.5 & 2.8 & 15.2 & - & - & - & - & 30 & 14.7 & 2.0 & 3.0 & 29 & 20.3 & 1.5 & 6.5 \\
\hline 48 & 27 & 10.7 & 1.3 & 30.0 & 83 & 24.0 & 1.8 & 0.8 & 48 & 28.5 & 1.4 & 0.6 & 41 & 23.5 & 1.5 & 1.6 \\
\hline 352 & 43 & 10.0 & 6.6 & 26.4 & 43 & 20.2 & 3.0 & 13.0 & 31 & 16.2 & 2.0 & 6.8 & 54 & 19.0 & 2.1 & 5.9 \\
\hline 33 & 35 & 13.0 & 4.7 & 28.3 & 37 & 20.5 & 2.2 & 4.8 & 31 & 35.0 & 4.2 & 4.1 & - & - & - & - \\
\hline $358 \ddagger$ & 30 & 9.5 & 0.8 & 12.2 & 33 & 16.0 & 1.6 & 2.2 & 92 & 34.0 & 1.6 & 1.4 & - & - & - & - \\
\hline $272 \ddagger$ & 38 & 9.7 & 2.3 & 16.7 & 131 & 34.5 & 1.4 & 0 & 147 & 36.7 & 1.0 & 0 & - & - & - & - \\
\hline $46 \ddagger$ & 36 & 11.5 & 1.8 & 14.4 & 30 & 14.3 & 1.8 & 4.1 & - & - & - & - & - & - & - & - \\
\hline $377 \ddagger$ & 26 & 9.3 & 3.1 & 28.9 & 122 & 30.0 & 1.0 & 1.6 & 63 & 30.0 & 0.6 & 0.5 & 81 & 49.0 & 1.3 & 0.4 \\
\hline $405 \ddagger$ & 28 & 9.8 & 1.5 & 16.5 & 143 & 32.5 & 2.7 & 1.3 & 115 & 26.8 & 2.0 & 0.4 & 142 & 35.0 & 0.5 & 0.9 \\
\hline 481 & 53 & 13.0 & 2.3 & 22.7 & 41 & 20.7 & 1.0 & 1.8 & - & - & - & - & 76 & 29.0 & 2.4 & 1.2 \\
\hline 212 & 55 & 12.5 & 3.4 & 14.7 & 60 & 18.0 & 3.5 & 3.5 & 141 & 46.5 & 2.8 & 0.4 & - & - & - & - \\
\hline 419 & 38 & 11.3 & 2.0 & 18.2 & - & - & - & - & 38 & 19.0 & 1.5 & 3.0 & - & - & - & - \\
\hline $53 \ddagger$ & 43 & 11.9 & 1.2 & 12.6 & & & & & 98 & 39.0 & 1.3 & 0.3 & & & & \\
\hline Mean & 35 & 11.2 & 2.9 & 21.3 & 71 & 24.7 & 2.6 & 3.5 & 81.6 & 29.7 & 2.1 & 1.9 & 91 & 32.9 & 1.9 & 1.8 \\
\hline SEM & 2.1 & 0.38 & 0.34 & 1.81 & 11.4 & 1.83 & 0.33 & 0.84 & 16.3 & 2.03 & 0.28 & 0.48 & 20.6 & 4.01 & 0.22 & 0.53 \\
\hline \multicolumn{17}{|c|}{ Controls $\S$} \\
\hline Mean & 35 & 11.6 & 2.8 & 19.7 & 31 & 12.6 & 2.9 & 23.0 & 34 & 13.2 & 2.7 & 20.3 & 36 & 16.2 & 2.6 & 21.8 \\
\hline SEM & 2.5 & 0.60 & 0.42 & 2.91 & 1.3 & 0.89 & 0.44 & 5.32 & 3.3 & 0.74 & 0.55 & 3.07 & 5.4 & 1.11 & 0.51 & 3.98 \\
\hline \multicolumn{17}{|c|}{ Second pregnancy } \\
\hline $358 \ddagger$ & 140 & 35.3 & 3.0 & 0.0 & - & 一 & - & 一 & 一 & 一 & 一 & - & 一 & - & - & - \\
\hline $216 \ddagger$ & 91 & 27.0 & 0.9 & 0.5 & - & - & 一 & - & - & - & - & - & - & - & - & - \\
\hline 350 & 41 & 29.5 & 1.4 & 1.5 & - & - & - & - & - & - & - & - & 67 & 29.5 & 3.2 & 0.5 \\
\hline 404 & 105 & 34.0 & 2.3 & 0.7 & - & - & - & - & 126 & 36.0 & 1.0 & 0.6 & - & - & - & - \\
\hline 335 & 47 & 23.0 & 2.0 & 4.0 & 34 & 15.0 & 1.3 & 6.6 & 34 & 15.5 & 0.6 & 7.2 & - & - & - & - \\
\hline 48 & 48 & 23.5 & 3.0 & 1.6 & - & - & - & - & 137 & 27.5 & 1.2 & 0.1 & - & - & - & - \\
\hline 309 & 39 & 20 & 1.7 & 2.3 & - & - & - & - & 59 & 17.0 & 2.4 & 2.4 & - & - & - & - \\
\hline 352 & 38 & 13.0 & 1.7 & 10.9 & - & - & - & - & 40 & 18.0 & 1.9 & 5.5 & - & - & - & - \\
\hline
\end{tabular}

* FBS, fasting plasma glucose concentration; $T \frac{1}{2}$, plasma glucose disappearance halftime; FIRI, fasting plasma immunoreactive insulin concentration Max $\triangle I R I$, maximum increment from base line plasma insulin concentration.

Intrauterine fetal death.

$\$ 20$ concurrent control normal pregnancies. 
val in the streptozotocin-treated animals was significantly greater than in control animals $(71 \pm 11.4$ vs. $31 \pm 1.3,81.6 \pm 16.3$ vs. $34 \pm 3.3$, and $91 \pm 20.6$ vs. $36 \pm 5.4 \mathrm{mg} / 100 \mathrm{ml}$ plasma, $P<0.01$ ). However, there is a wide distribution in the values from each individual animal in the streptozotocin-treated group. The data from four of the animals $(216,404,272,405)$ markedly skew the mean upward, and that from four other animals $(255,335,352,33)$ did not differ from the mean of the control group.

The mean plasma glucose disappearance half time obtained in the first trimester for the control animals increased 1.4 times before delivery; that for the streptozotocin-treated group 2.9 times. Again, a wide distribution is noted in the individual values for the streptozotocin-treated group with an increment range from 1.5 to 7.6. Although the mean of the plasma glucose disappearance half time did increase throughout gestation in the streptozotocin group, no consistent trends in sequential samples for individual animals were observed.

The mean maternal fasting plasma immunoractive insulin concentrations in the treated group $(2.3 \pm 0.18$ $\mathrm{ng} / \mathrm{ml}$ plasma, 49 observations) and nontreated group $(2.7 \pm 0.17 \mathrm{ng} / \mathrm{ml}$ plasma, 53 observations $)$ during pregnancy are not significantly different. The means of the maximum increment from base line maternal plasma insulin concentrations in response to intravenously administered glucose do contrast. In the control group the values after the first trimester in sequence were $23.0 \pm 5.3,20.3 \pm 3.1$, and $21.8 \pm 3.9 \mathrm{ng} / \mathrm{ml}$. The group which received streptozotocin demonstrated a markedly attenuated pancreatic islet cell response with sequential mean values of $3.5 \pm 0.8,1.9 \pm 0.5$, and $1.8 \pm 0.5 \mathrm{ng} / \mathrm{ml}$, respectively. Although the plasma insulin responses from individual monkeys in the treated group were consistent from one test period to another, as with the other data in Table II, there is a wide range in the individual maximum plasma insulin increments.

Seven streptozotocin-treated animals delivered eight deadborns. These were animals 46, 272, 358, 216, 53, 405, and 377 which delivered at $96,117,117,120,131,142$, and 144 days gestation, respectively. Animal 358 delivered a second deadborn at 130 days. The last seven fetuses were recovered before they were cannibalized; they weighed $0.23,0.22,0.25,0.36,0.32,0.43$, and 0.30 $\mathrm{kg}$, respectively. As detailed below, the deadborn at 142 days was larger than the mean \pm 2 SEM for this gestational age (Fig. 1); the other fetal weights were in accord with or less than the reported normal range at this time in gestation (20-22). During the past $4 \mathrm{yr}$, no second or third trimester deadborns have been delivered in the last $\mathbf{1 7 1}$ gestations conceived in this colony.

Of the remaining 21 pregnancies, 17 were delivered by elective cesarean section between 137-148 days gestation

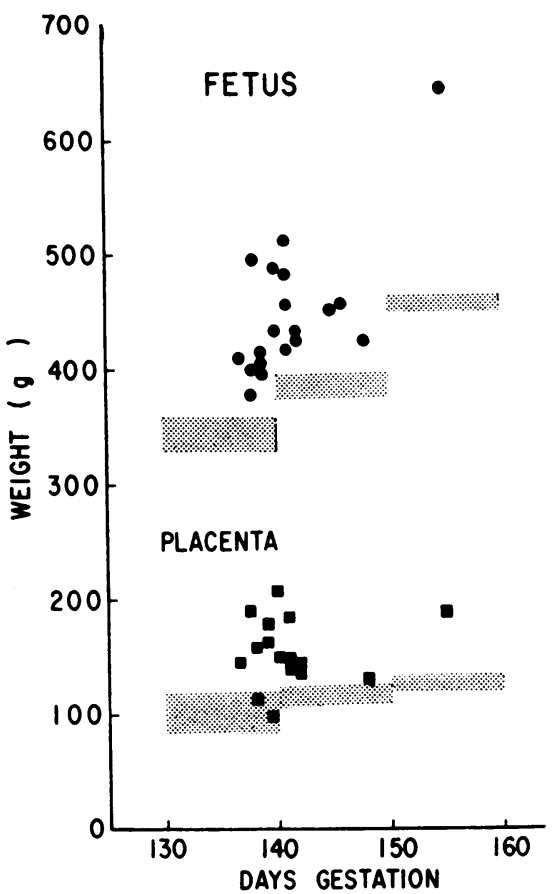

FIGURE 1 The fetal-neonatal and placental weights of the streptozotocin-treated pregnancies $(\boldsymbol{\bullet}, \boldsymbol{\square})$ compared to the reported means \pm 2 SEM (stippled areas) of 473 fetus-neonates and 131 placentas delivered from normal rhesus pregnancies (20-24).

and the 4 others $(216,335,404$, and 33$)$ spontaneously delivered vaginally between 142 and 155 days gestation. The available fetal-neonatal birth and placental weights are depicted in Fig. 1. All of the fetal weights and most of the placental weights exceed the stippled rectangles which identify the means \pm 2 sEM of 473 fetal weights and 131 placental weights recorded from normal gestations reported in the literature (20-24). Eight of the treated animals had had a previous normal pregnancy delivered near term before the streptozotocin-treated pregnancy. Five of the control animals also had previously delivered near term. All the fetal and placental weights of the present control and the previous normal pregnancies were within the reported normal ranges.

The mean \pm 2 SEM of 62 amniotic fluid volumes from the control animals and other normal rhesus monkey pregnancies reported in the literature $(20,22)$ is $87 \pm 13$ $\mathrm{ml}$ at $139-148$ days gestation. Amniotic fluid volume was available for measurement in 18 streptozotocintreated pregnancies. The range of these values was $104-458 \mathrm{ml}$ with a mean of $190 \mathrm{ml}$. This was significantly different from normal $(P<0.01)$. There was no correlation between maternal oral fluid intake, urinary output, magnitude of glucosuria, or extent of induced glucose intolerance and the measured amniotic fluid volume. Therefore, in the third trimester, statistically signifi- 
TABLE III

Effect of the Administration of Intravascular Glucose to the Fetus, Mother, or Neonate on the Plasma

\begin{tabular}{|c|c|c|c|c|c|c|}
\hline \multirow[b]{2}{*}{ Animal } & \multirow[b]{2}{*}{ Amount } & \multirow[b]{2}{*}{ Site } & \multirow{2}{*}{$\begin{array}{c}\text { Plasma } \\
\text { assay }\end{array}$} & \multicolumn{3}{|c|}{ Time $(\min )$} \\
\hline & & & & 0 & 2 & 5 \\
\hline $255 \mathrm{~F}$ & $\begin{array}{l}250 \mathrm{mg} \text { glucose injected at } \\
0 \mathrm{~min}\end{array}$ & $\begin{array}{l}\text { Maternal } \\
\text { vena cava }\end{array}$ & $\begin{array}{l}\mathrm{CHO}^{*} \\
\text { INS } \ddagger \\
\text { SGH§ } \\
\text { CHO } \\
\text { INS }\end{array}$ & $\begin{array}{c}27 \\
1.9 \\
11 \\
40 \\
2.2\end{array}$ & $\begin{array}{l}71 \\
2.7 \\
9\end{array}$ & $\begin{array}{c}64 \\
5.6 \\
8 \\
37 \\
2.0\end{array}$ \\
\hline $350 \mathrm{~F}$ & $\begin{array}{l}250 \mathrm{mg} \text { glucose injected at } \\
0 \mathrm{~min}\end{array}$ & $\begin{array}{l}\text { Fetal artery } \\
\text { Maternal } \\
\text { vena cava }\end{array}$ & $\begin{array}{l}\text { CHO } \\
\text { INS } \\
\text { SGH } \\
\text { CHO } \\
\text { INS }\end{array}$ & $\begin{array}{l}29 \\
2.0 \\
6 \\
41 \\
3.0\end{array}$ & $\begin{array}{l}127 \\
3.0 \\
6\end{array}$ & $\begin{array}{c}78 \\
9.1 \\
7 \\
53 \\
3.7\end{array}$ \\
\hline $309 \mathrm{~F}$ & $\begin{array}{l}250 \mathrm{mg} \text { glucose injected at } \\
0 \mathrm{~min}, 20 \mathrm{mg} / \mathrm{min} \text { glucose } \\
\text { infused } 0-15 \mathrm{~min}\end{array}$ & $\begin{array}{l}\text { Fetal vein } \\
\text { Maternal } \\
\text { vena cava }\end{array}$ & $\begin{array}{l}\text { CHO } \\
\text { INS } \\
\text { SGH } \\
\text { CHO } \\
\text { INS }\end{array}$ & $\begin{array}{c}47 \\
2.9 \\
11 \\
60 \\
3.4\end{array}$ & & \\
\hline $219 \mathrm{~F}$ & $\begin{array}{l}250 \mathrm{mg} \text { glucose injected at } \\
0 \mathrm{~min}, 50 \mathrm{mg} / \mathrm{min} \text { glucose } \\
\text { infused } 0-10 \mathrm{~min}\end{array}$ & $\begin{array}{l}\text { Fetal vein } \\
\text { Maternal } \\
\text { vena cava }\end{array}$ & $\begin{array}{l}\text { CHO } \\
\text { INS } \\
\text { SGH } \\
\text { CHO } \\
\text { INS }\end{array}$ & $\begin{array}{c}110 \\
4.1 \\
5 \\
116 \\
1.8\end{array}$ & & \\
\hline $446 \mathrm{M}$ & $\begin{array}{l}3.4 \mathrm{~g} \text { glucose injected at } \\
0 \mathrm{~min}\end{array}$ & $\begin{array}{l}\text { Maternal } \\
\text { vena cava }\end{array}$ & $\begin{array}{l}\text { CHO } \\
\text { INS } \\
\text { SGH } \\
\text { CHO } \\
\text { INS }\end{array}$ & $\begin{array}{c}60 \\
2.9 \\
11 \\
73 \\
3.3\end{array}$ & & $\begin{array}{r}251 \\
\quad 3.7\end{array}$ \\
\hline $35 \mathrm{M}$ & $\begin{array}{l}4.2 \mathrm{~g} \text { glucose injected at } \\
0 \mathrm{~min}\end{array}$ & $\begin{array}{l}\text { Maternal } \\
\text { vena cava }\end{array}$ & $\begin{array}{l}\text { CHO } \\
\text { INS } \\
\text { SGH } \\
\text { CHO } \\
\text { INS }\end{array}$ & $\begin{array}{l}39 \\
2.0 \\
7 \\
56 \\
1.9\end{array}$ & & $\begin{array}{r}216 \\
2.7\end{array}$ \\
\hline $216 \mathrm{~N}$ & $\begin{array}{l}250 \mathrm{mg} \text { glucose injected at } \\
0 \mathrm{~min}\end{array}$ & $\begin{array}{l}\text { Umbilical } \\
\text { vein }\end{array}$ & $\begin{array}{l}\text { CHO } \\
\text { INS } \\
\text { SGH }\end{array}$ & $\begin{array}{c}45 \\
4.3 \\
7\end{array}$ & $\begin{array}{c}305 \\
8.0 \\
6\end{array}$ & $\begin{array}{c}235 \\
9.2 \\
6\end{array}$ \\
\hline $404 \mathrm{~N}$ & $\begin{array}{l}250 \mathrm{mg} \text { glucose injected at } \\
0 \mathrm{~min}\end{array}$ & $\begin{array}{l}\text { Umbilical } \\
\text { vein }\end{array}$ & $\begin{array}{l}\text { CHO } \\
\text { INS } \\
\text { SGH }\end{array}$ & $\begin{array}{l}51 \\
4.1 \\
4\end{array}$ & $\begin{array}{c}240 \\
14.8 \\
3\end{array}$ & $\begin{array}{c}204 \\
12.6 \\
2\end{array}$ \\
\hline $335 \mathrm{~N}$ & $\begin{array}{l}250 \mathrm{mg} \text { glucose injected at } \\
0 \mathrm{~min}\end{array}$ & $\begin{array}{l}\text { Umbilical } \\
\text { vein }\end{array}$ & $\begin{array}{l}\text { CHO } \\
\text { INS } \\
\text { SGH }\end{array}$ & $\begin{array}{c}40 \\
1.0 \\
14\end{array}$ & $\begin{array}{c}236 \\
7.4 \\
14\end{array}$ & $\begin{array}{c}193 \\
3.4 \\
12\end{array}$ \\
\hline
\end{tabular}

* Plasma glucose, $\mathrm{mg} / 100 \mathrm{ml}$.

$\ddagger$ Plasma insulin, $\mathrm{ng} / \mathrm{ml}$.

$\S$ Plasma growth hormone, $\mu \mathrm{g} / \mathrm{ml}$.

cant increases in both fetal and placental weights and in the volume of amniotic fluid were found in the streptozotocin-treated pregnancies.

The fetal and maternal plasma glucose, insulin, and growth hormone responses to fetal glucose intravascular injections, combined fetal glucose intravascular in- jections and infusions, and maternal glucose intravenous injections are recorded in Table III. In two fetuses who received an injection of glucose alone (255 F, $350 \mathrm{~F}$ ), the induced fetal hyperglycemia was associated with a prompt rise in the fetal plasma insulin concentrations, a reversal of the maternal-fetal insulin concen- 
Glucose, Growth Hormone, and Insulin Concentrations in Streptozotocin-Treated Pregnancies

\begin{tabular}{|c|c|c|c|c|c|c|}
\hline \multicolumn{6}{|c|}{ Time $(\min )$} & \multirow[b]{2}{*}{ Comments } \\
\hline 10 & 15 & 20 & 30 & 40 & 60 & \\
\hline 55 & & 39 & & 33 & 36 & 141 day gestation, mother $6.8 \mathrm{~kg}$, male fetus \\
\hline 5.8 & & 3.7 & & 2.8 & 2.2 & $0.51 \mathrm{~kg}$, placenta $0.18 \mathrm{~kg}$, amniotic fluid \\
\hline 10 & & 11 & & 13 & 13 & $133 \mathrm{ml}$. \\
\hline 39 & & 37 & & 40 & 40 & \\
\hline 2.0 & & 2.0 & & 1.9 & 2.0 & \\
\hline 61 & & 32 & & 32 & 32 & 141 day gestation, mother $7.3 \mathrm{~kg}$, female fetus \\
\hline 7.7 & & 4.0 & & 2.5 & 2.1 & $0.42 \mathrm{~kg}$, placenta $0.15 \mathrm{~kg}$, amniotic fluid \\
\hline 9 & & 7 & & 9 & 9 & $135 \mathrm{ml}$. \\
\hline 53 & & 50 & & 31 & 34 & \\
\hline \multirow[t]{6}{*}{2.9} & & 2.0 & & 2.0 & 2.0 & \\
\hline & 178 & & 110 & 58 & 50 & 148 day gestation, mother $6.6 \mathrm{~kg}$, female fetus \\
\hline & 4.2 & & 5.7 & 6.4 & 5.5 & $0.43 \mathrm{~kg}$, placenta $0.13 \mathrm{~kg}$, amniotic fluid \\
\hline & 13 & & 15 & 14 & 15 & $121 \mathrm{ml}$. \\
\hline & 75 & & 69 & 63 & 61 & \\
\hline & 3.4 & & 3.4 & 3.4 & 3.4 & \\
\hline 205 & & 151 & 129 & 107 & 95 & 139 day gestation, mother $5.5 \mathrm{~kg}$, male fetus \\
\hline 8.0 & & 7.6 & 6.8 & 6.4 & 5.8 & $0.40 \mathrm{~kg}$, placenta $0.18 \mathrm{~kg}$, amniotic fluid \\
\hline 5 & & 4 & 4 & 3 & 5 & $242 \mathrm{ml}$. \\
\hline 128 & & 119 & 120 & 109 & 95 & \\
\hline \multirow[t]{4}{*}{1.9} & & 2.1 & 1.8 & 1.7 & 1.6 & \\
\hline & 137 & & 107 & & & 141 day gestation, mother $6.8 \mathrm{~kg}$, female fetus \\
\hline & 4.1 & & 3.3 & & & $0.48 \mathrm{~kg}$, placenta $0.15 \mathrm{~kg}$, amniotic fluid, \\
\hline & 11 & & 13 & & & $186 \mathrm{ml}$. \\
\hline 193 & 157 & 130 & 108 & & & \\
\hline \multirow[t]{4}{*}{3.5} & 3.3 & 2.6 & 2.6 & & & \\
\hline & 146 & & 110 & & & 140 day gestation, mother $8.4 \mathrm{~kg}$, female fetus \\
\hline & 7.6 & & 7.0 & & & $0.49 \mathrm{~kg}$, placenta $0.21 \mathrm{~kg}$, amniotic fluid, \\
\hline & 5 & & 7 & & & $325 \mathrm{ml}$. \\
\hline 186 & 160 & 139 & 119 & & & \\
\hline 3.4 & 2.3 & 2.4 & 2.0 & & & \\
\hline 195 & & 178 & & 138 & 113 & $6 \mathrm{hr}$ of life, female $0.46 \mathrm{~kg}, 146$ day gestation, \\
\hline 7.5 & & 5.4 & & 4.4 & 3.3 & no placenta, no amniotic fluid. \\
\hline 6 & & 5 & & 4 & 3 & \\
\hline 157 & & 111 & & 59 & 47 & $8 \mathrm{hr}$ of life, female $0.65 \mathrm{~kg}, 155$ day gestation, \\
\hline 11.2 & & 8.5 & & 4.1 & 3.3 & placenta $0.19 \mathrm{~kg}$, no amniotic fluid. \\
\hline 3 & & 2 & & 4 & 5 & \\
\hline 162 & & 121 & & 87 & 52 & $8 \mathrm{hr}$ of life, male $0.45 \mathrm{~kg}, 144$ day gestation, \\
\hline 2.5 & & 2.4 & & 2.0 & 1.2 & no placenta, no amniotic fluid. \\
\hline 15 & & 14 & & 14 & 12 & \\
\hline
\end{tabular}

tration ratio, and a return to base line insulin concentrations by $60 \mathrm{~min}$. In $350 \mathrm{~F}$, the transfer of glucose across the placenta to the mother was also associated with a small increase in maternal plasma insulin concentrations. In the two other fetal experiments (309 F, $219 \mathrm{~F}$ ), the combined intravenous injection and infusion of glucose to the fetus resulted in a more prolonged fetal hyperglycemia and a more sustained augmentation of fetal plasma insulin levels.

Direct maternal hyperglycemia was induced in two other experiments ( $446 \mathrm{M}, 35 \mathrm{M})$. Fetal hyperglycemia was evident at $15 \mathrm{~min}$ as were elevated fetal plasma in- 


\section{TABLE IV}

Effect of the Intravascular Infusion of Mixed Amino Acid* to the Fetus and Neonate on the Plasma Glucose, Growth Hormone, and Insulin Concentrations in Normal and Streptozotocin-Treated Pregnancies

\begin{tabular}{|c|c|c|c|c|c|c|c|c|c|}
\hline \multirow[b]{2}{*}{ Animal } & \multirow[b]{2}{*}{ Amount } & \multirow[b]{2}{*}{ Site } & \multirow{2}{*}{$\begin{array}{c}\text { Plasma } \\
\text { assay }\end{array}$} & \multicolumn{5}{|c|}{ Time (min) } & \multirow[b]{2}{*}{ Comments } \\
\hline & & & & 0 & 15 & 30 & 45 & 60 & \\
\hline $\begin{array}{l}320 \mathrm{~F} \\
\text { Normal }\end{array}$ & $\begin{array}{l}2 \mathrm{mg} / \mathrm{min} \text { infused } \\
\text { at } 0-30 \mathrm{~min}\end{array}$ & $\begin{array}{l}\text { Maternal } \\
\text { vena cava }\end{array}$ & $\begin{array}{l}\text { CHO } \ddagger \\
\text { INS\& } \\
\text { GH\| } \\
\text { CHO } \\
\text { INS }\end{array}$ & $\begin{array}{c}27 \\
0.3 \\
15 \\
36 \\
1.0\end{array}$ & $\begin{array}{c}27 \\
0.3 \\
17 \\
37 \\
1.2\end{array}$ & $\begin{array}{c}33 \\
0.4 \\
17 \\
37 \\
1.2\end{array}$ & $\begin{array}{c}33 \\
0.3 \\
17 \\
36 \\
0.9\end{array}$ & $\begin{array}{c}36 \\
0.4 \\
17 \\
40 \\
1.4\end{array}$ & $\begin{array}{l}148 \text { day gestation, mother } 7.3 \mathrm{~kg} \text {, female fetus } \\
0.40 \mathrm{~kg} \text {, placenta } 0.11 \mathrm{~kg} \text {, amniotic fluid } \\
90 \mathrm{ml} \text {. }\end{array}$ \\
\hline $\begin{array}{l}296 \mathrm{~F} \\
\text { Normal }\end{array}$ & $\begin{array}{l}2 \mathrm{mg} / \mathrm{min} \text { infused } \\
\text { at } 0-30 \mathrm{~min}\end{array}$ & $\begin{array}{l}\text { Maternal } \\
\text { vena cava }\end{array}$ & $\begin{array}{l}\text { CHO } \\
\text { INS } \\
\text { GH } \\
\text { CHO } \\
\text { INS }\end{array}$ & $\begin{array}{c}34 \\
0.6 \\
18 \\
42 \\
1.2\end{array}$ & $\begin{array}{c}34 \\
0.6 \\
18 \\
42 \\
1.1\end{array}$ & $\begin{array}{c}35 \\
0.6 \\
16 \\
40 \\
1.2\end{array}$ & $\begin{array}{c}36 \\
0.6 \\
18 \\
44 \\
1.4\end{array}$ & $\begin{array}{c}36 \\
0.6 \\
19 \\
42 \\
1.2\end{array}$ & $\begin{array}{l}151 \text { day gestation, mother } 7.1 \mathrm{~kg} \text {, male fetus } \\
0.51 \mathrm{~kg} \text {, placenta } 0.13 \mathrm{~kg} \text {, amniotic fluid } \\
96 \mathrm{ml} \text {. }\end{array}$ \\
\hline $\begin{array}{l}278 \mathrm{~F} \\
\text { Normal }\end{array}$ & $\begin{array}{l}20 \mathrm{mg} / \mathrm{min} \text { infused } \\
\text { at } 0-30 \mathrm{~min}\end{array}$ & $\begin{array}{l}\text { Maternal } \\
\text { vena cava }\end{array}$ & $\begin{array}{l}\text { CHO } \\
\text { INS } \\
\text { GH } \\
\text { CHO } \\
\text { INS }\end{array}$ & $\begin{array}{c}42 \\
1.2 \\
14 \\
49 \\
1.0\end{array}$ & $\begin{array}{c}40 \\
3.8 \\
15 \\
52 \\
1.4\end{array}$ & $\begin{array}{c}42 \\
2.8 \\
13 \\
53 \\
2.4\end{array}$ & $\begin{array}{c}43 \\
1.2 \\
13 \\
53 \\
1.7\end{array}$ & $\begin{array}{c}47 \\
1.2 \\
12 \\
56 \\
1.9\end{array}$ & $\begin{array}{l}150 \text { day gestation, mother } 8.6 \mathrm{~kg} \text {, female fetus } \\
0.42 \mathrm{~kg} \text {, placenta } 0.14 \mathrm{~kg} \text {, amniotic fluid } \\
79 \mathrm{ml} \text {. }\end{array}$ \\
\hline $335 \mathrm{~F}$ & $\begin{array}{l}2 \mathrm{mg} / \mathrm{min} \text { infused } \\
\text { at } 0-30 \mathrm{~min}\end{array}$ & $\begin{array}{l}\text { Maternal } \\
\text { vena cava }\end{array}$ & $\begin{array}{l}\text { CHO } \\
\text { INS } \\
\text { GH } \\
\text { CHO } \\
\text { INS }\end{array}$ & $\begin{array}{c}56 \\
0.7 \\
7 \\
69 \\
1.7\end{array}$ & $\begin{array}{c}56 \\
2.0 \\
8 \\
70 \\
1.7\end{array}$ & $\begin{array}{c}56 \\
1.8 \\
7 \\
69 \\
1.5\end{array}$ & $\begin{array}{c}64 \\
1.6 \\
7 \\
69 \\
1.7\end{array}$ & $\begin{array}{c}67 \\
1.2 \\
7 \\
73 \\
1.6\end{array}$ & $\begin{array}{l}138 \text { day gestation, mother } 6.8 \mathrm{~kg} \text {, male fetus } \\
0.37 \text {, placenta } 0.11 \mathrm{~kg} \text {, amniotic fluid, } 124 \mathrm{ml} \text {. }\end{array}$ \\
\hline $481 \mathrm{~F}$ & $\begin{array}{l}2 \mathrm{mg} / \mathrm{min} \text { infused } \\
\text { at } 0-30 \mathrm{~min}\end{array}$ & $\begin{array}{l}\text { Maternal } \\
\text { vena cava }\end{array}$ & $\begin{array}{l}\text { CHO } \\
\text { INS } \\
\text { GH } \\
\text { CHO } \\
\text { INS }\end{array}$ & $\begin{array}{c}70 \\
1.4 \\
9 \\
80 \\
1.0\end{array}$ & $\begin{array}{c}69 \\
2.8 \\
9 \\
82 \\
1.0\end{array}$ & $\begin{array}{c}72 \\
2.4 \\
9 \\
84 \\
1.1\end{array}$ & $\begin{array}{c}76 \\
2.0 \\
10 \\
86 \\
1.2\end{array}$ & $\begin{array}{l}76 \\
1.8 \\
8 \\
86 \\
1.2\end{array}$ & $\begin{array}{l}139 \text { day gestation, mother } 6.4 \mathrm{~kg} \text {, male fetus } \\
0.38 \mathrm{~kg} \text {, placenta } 0.09 \mathrm{~kg} \text {, amniotic fluid } \\
105 \mathrm{ml} \text {. }\end{array}$ \\
\hline $352 \mathrm{~F}$ & $\begin{array}{l}20 \mathrm{mg} / \mathrm{min} \text { infused } \\
\text { at } 0-30 \mathrm{~min}\end{array}$ & $\begin{array}{l}\text { Maternal } \\
\text { vena cava }\end{array}$ & $\begin{array}{l}\text { CHO } \\
\text { INS } \\
\text { GH } \\
\text { CHO } \\
\text { INS }\end{array}$ & $\begin{array}{c}75 \\
1.9 \\
9 \\
89 \\
2.4\end{array}$ & $\begin{array}{c}73 \\
3.2 \\
8 \\
84 \\
2.4\end{array}$ & $\begin{array}{c}76 \\
2.9 \\
9 \\
84 \\
2.0\end{array}$ & $\begin{array}{l}79 \\
2.2 \\
8 \\
86 \\
2.3\end{array}$ & $\begin{array}{c}78 \\
1.9 \\
8 \\
86 \\
2.0\end{array}$ & $\begin{array}{l}141 \text { day gestation, mother } 7.9 \mathrm{~kg} \text {, female fetus } \\
0.39 \mathrm{~kg} \text {, placenta } 0.14 \mathrm{~kg} \text {, amniotic fluid } \\
157 \mathrm{ml} \text {. }\end{array}$ \\
\hline $\begin{array}{l}246 \mathrm{~N} \\
\text { Normal }\end{array}$ & $\begin{array}{l}2 \mathrm{mg} / \mathrm{min} \text { infused } \\
\text { at } 0-30 \mathrm{~min}\end{array}$ & $\begin{array}{l}\text { Umbilical } \\
\text { vein }\end{array}$ & $\begin{array}{l}\text { CHO } \\
\text { INS } \\
\text { GH }\end{array}$ & $\begin{array}{l}55 \\
0.9 \\
6\end{array}$ & $\begin{array}{l}55 \\
0.9 \\
6\end{array}$ & $\begin{array}{l}58 \\
0.9 \\
5\end{array}$ & $\begin{array}{l}62 \\
0.8 \\
b\end{array}$ & $\begin{array}{c}62 \\
0.9 \\
5\end{array}$ & $\begin{array}{l}5 \mathrm{hr} \text { of life, male } 0.40 \mathrm{~kg}, 147 \text { days gestation, } \\
\text { placenta } 0.12 \mathrm{~kg} \text {, no amniotic fluid. }\end{array}$ \\
\hline $\begin{array}{l}476 \mathrm{~N} \\
\text { Normal }\end{array}$ & $\begin{array}{l}2 \mathrm{mg} / \mathrm{min} \text { infused } \\
\text { at } 0-30 \mathrm{~min}\end{array}$ & $\begin{array}{l}\text { Umbilical } \\
\text { vein }\end{array}$ & $\begin{array}{l}\text { CHO } \\
\text { INS } \\
\text { GH }\end{array}$ & $\begin{array}{l}29 \\
0.7 \\
9\end{array}$ & $\begin{array}{c}29 \\
0.6 \\
10\end{array}$ & $\begin{array}{c}33 \\
0.6 \\
8\end{array}$ & $\begin{array}{c}37 \\
0.6 \\
7\end{array}$ & $\begin{array}{c}37 \\
0.6 \\
7\end{array}$ & $\begin{array}{l}5 \mathrm{hr} \text { of life, female } 0.36 \mathrm{~kg}, 145 \text { days gestation, } \\
\text { placenta } 0.11 \mathrm{~kg} \text {, no amniotic fluid. }\end{array}$ \\
\hline $\begin{array}{l}535 \mathrm{~N} \\
\text { Normal }\end{array}$ & $\begin{array}{l}20 \mathrm{mg} / \mathrm{min} \text { infused } \\
\text { at } 0-30 \mathrm{~min}\end{array}$ & $\begin{array}{l}\text { Umbilical } \\
\text { vein }\end{array}$ & $\begin{array}{l}\text { CHO } \\
\text { INS } \\
\text { GH }\end{array}$ & $\begin{array}{c}30 \\
0.7 \\
5\end{array}$ & $\begin{array}{c}29 \\
4.3 \\
4\end{array}$ & $\begin{array}{c}34 \\
2.9 \\
5\end{array}$ & $\begin{array}{c}39 \\
2.4 \\
4\end{array}$ & $\begin{array}{l}40 \\
1.8 \\
6\end{array}$ & $\begin{array}{l}5 \mathrm{hr} \text { of life, female } 0.32 \mathrm{~kg}, 149 \text { days gestation, } \\
\text { placenta } 0.08 \mathrm{~kg} \text {, amniotic fluid } 80 \mathrm{ml} \text {. }\end{array}$ \\
\hline $\begin{array}{l}278 \mathrm{~N} \\
\text { Normal }\end{array}$ & $\begin{array}{l}20 \mathrm{mg} / \mathrm{min} \text { infused } \\
\text { at } 0-30 \mathrm{~min}\end{array}$ & $\begin{array}{l}\text { Umbilical } \\
\text { vein }\end{array}$ & $\begin{array}{l}\text { CHO } \\
\text { INS } \\
\text { GH }\end{array}$ & $\begin{array}{c}26 \\
1.5 \\
7\end{array}$ & $\begin{array}{c}24 \\
6.0 \\
7\end{array}$ & $\begin{array}{c}28 \\
4.2 \\
8\end{array}$ & $\begin{array}{c}36 \\
3.2 \\
7\end{array}$ & $\begin{array}{c}36 \\
3.2 \\
7\end{array}$ & $\begin{array}{l}5 \mathrm{hr} \text { of life, female } 0.42 \mathrm{~kg}, 150 \text { day gestation, } \\
\text { placenta } 0.14 \mathrm{~kg} \text {, amniotic fluid } 79 \mathrm{ml} \text {. }\end{array}$ \\
\hline $352 \mathrm{~N}$ & $\begin{array}{l}2 \mathrm{mg} / \mathrm{min} \text { infused } \\
\text { at } 0-30 \mathrm{~min}\end{array}$ & $\begin{array}{l}\text { Umbilical } \\
\text { vein }\end{array}$ & $\begin{array}{l}\text { CHO } \\
\text { INS } \\
\text { GH }\end{array}$ & $\begin{array}{c}36 \\
1.0 \\
7\end{array}$ & $\begin{array}{l}36 \\
3.2 \\
7\end{array}$ & $\begin{array}{l}47 \\
2.1 \\
8\end{array}$ & $\begin{array}{l}47 \\
2.2 \\
6\end{array}$ & $\begin{array}{l}51 \\
1.9 \\
7\end{array}$ & $\begin{array}{l}5 \mathrm{hr} \text { of life, male } 0.40 \mathrm{~kg}, 138 \text { day gestation, } \\
\text { placenta } 0.16 \mathrm{~kg} \text {, amniotic fluid } 209 \mathrm{ml} \text {. }\end{array}$ \\
\hline $33 \mathrm{~N}$ & $\begin{array}{l}2 \mathrm{mg} / \mathrm{min} \text { infused } \\
\text { at } 0-30 \mathrm{~min}\end{array}$ & $\begin{array}{l}\text { Umbilical } \\
\text { vein }\end{array}$ & $\begin{array}{l}\text { CHO } \\
\text { INS } \\
\text { GH }\end{array}$ & $\begin{array}{l}50 \\
2.6 \\
7\end{array}$ & $\begin{array}{l}51 \\
5.0 \\
8\end{array}$ & $\begin{array}{l}58 \\
3.8 \\
6\end{array}$ & $\begin{array}{l}60 \\
3.3 \\
5\end{array}$ & $\begin{array}{l}59 \\
2.8 \\
6\end{array}$ & $\begin{array}{l}7 \mathrm{hr} \text { of life, female } 0.44 \mathrm{~kg}, 142 \text { days gestation, } \\
\text { placenta } 0.12 \mathrm{~kg} \text {, no amniotic fluid. }\end{array}$ \\
\hline $419 \mathrm{~N}$ & $\begin{array}{l}20 \mathrm{mg} / \mathrm{min} \text { infused } \\
\text { at } 0-30 \mathrm{~min}\end{array}$ & $\begin{array}{l}\text { Umbilical } \\
\text { vein }\end{array}$ & $\begin{array}{l}\text { CHO } \\
\text { INS } \\
\text { GH }\end{array}$ & $\begin{array}{l}60 \\
3.2 \\
9\end{array}$ & $\begin{array}{l}61 \\
8.1 \\
6\end{array}$ & $\begin{array}{c}66 \\
7.6 \\
7\end{array}$ & $\begin{array}{l}71 \\
5.4 \\
7\end{array}$ & $\begin{array}{l}71 \\
5.0 \\
8\end{array}$ & $\begin{array}{c}6 \mathrm{hr} \text { of life, female } 0.44 \mathrm{~kg}, 140 \text { days gestation, } \\
\text { placenta } 0.15 \mathrm{~kg} \text {, amniotic fluid } 180 \mathrm{ml} \text {. }\end{array}$ \\
\hline
\end{tabular}

* Amino acids: arginine, lysine, phenylalanine, leucine, methionine, valine, histidine, isoleucine, and threonine prepared as in Reference 15. ¥ Plasma glucose $\mathbf{m g} / 100 \mathrm{ml}$.

\& Plasma insulin $\mathrm{ng} / \mathrm{ml}$.

II Plasma growth hormone $\mu \mathrm{g} / \mathrm{ml}$.

844 D. H. Mintz, R. A. Chez, and D. L. Hutchinson 
sulin concentrations and a reversal of the fetal-maternal insulin ratio. In none of these six experiments were fetal plasma growth hormone concentrations consistently altered.

The neonatal experiments are also recorded in Table III. Similar to the fetal experiments, the intravenous injection of glucose, $555-385 \mathrm{mg} / \mathrm{kg}$ body weight $(216 \mathrm{~N}$, $404 \mathrm{~N}, 335 \mathrm{~N}$ ), was associated with an immediate rise in plasma insulin. The neonatal plasma growth hormone concentrations were not consistently altered.

The fetal, maternal, and neonatal plasma glucose, insulin, and growth hormone responses to fetal and neonatal intravascular infusions of mixed amino acids are recorded in Table IV. Infusions of mixed amino acids to fetuses $(335,481,352)$ and neonates $(352,33,419)$ of streptozotocin-treated pregnancies were associated with an elevation in plasma immunoreactive insulin concentrations. The increase in the concentration of plasma insulin was observed at the first sampling (15 min) and occurred before any alteration in plasma glucose levels. The augmentation in fetal and neonatal plasma insulin levels was demonstrated with the infusion of both amino acid concentrations (20 and $2 \mathrm{mg}$ / $\mathrm{min})$. In contrast, an alteration in plasma insulin levels occurred only in association with the infusion of the higher $(20 \mathrm{mg} / \mathrm{min})$ amino acid concentration to the fetus $(278)$ and neonates $(535,278)$ from normal pregnancies. Fetal and neonatal plasma growth hormone concentrations were not consistently altered by the amino acid infusions in either normal or streptozotocintreated pregnancies.

\section{DISCUSSION}

A diabetes mellitus-like syndrome was consistently obtained after the administration of the pancreatic beta cell cytotoxin, streptozotocin, to rhesus monkeys before conception and during the first trimester of pregnancy. The conceptii of these streptozotocin-treated animals demonstrated changes similar to those encountered in pregnancies of women with diabetes mellitus $(25,26)$. Specifically, these simian neonates and placentas were statistically significantly heavier than average for their gestational age, polyhydramnios was consistently encountered, and a well defined increase in the incidence of third trimester stillbirths for this colony was observed. These clinical features were present in both gestations in which normal female rhesus monkeys were treated with streptozotocin before conception or during early gestation. Thus, the evidence is that the maternal metabolic alterations induced by the drug, streptozotocin, and not the immediate pharmacologic effects of drug per se, are responsible for the changes observed in fetal growth and development.

As a group the streptozotocin-treated females demon- strated diminished intravenous glucose tolerance and decreased glucose mediated insulin release. Pedersen and colleagues (4) were the first to suggest that fetal hyperinsulinism is associated with maternal carbohydrate intolerance. The present studies provide antenatal confirmation of this prevailing hypothesis. The mean fetal and neonatal plasma insulin concentration in the streptozotocin-treated pregnancies was $2.6 \pm 0.3 \mathrm{ng} / \mathrm{ml}$ and $2.4 \pm 0.6 \mathrm{ng} / \mathrm{ml}$, respectively. These are significantly different from the mean values obtained from our previously reported fetal and neonatal normal controls $(1,2), 0.7 \pm 0.1 \mathrm{ng} / \mathrm{ml}$ and $1.1 \pm 0.2 \mathrm{ng} / \mathrm{ml}$, respectively $(P<0.005)$. Therefore, hyperinsulinemia is present in the fetus during the third trimester as well as during early neonatal life, in pregnancies complicated by maternal glucose intolerance.

In addition to hyperinsulinemia, prompt and enhanced pancreatic islet cell responsiveness to induced hyperglycemia is found both in utero and in the newborn (Table III). In contrast, in normal pregnancies fetal plasma insulin levels are not significantly altered from base line despite the induction and maintenance of hyperglycemia (blood glucose $>300 \mathrm{mg} / 100 \mathrm{ml}$ ) for as long as 120 $\min (1)$.

The specific mechanism whereby the normal fetal pancreatic islet cell unresponsiveness to glucose is reversed remains unclear. The Pedersen hypothesis focuses upon the primary and critical role of persistent or intermittent maternal-fetal hyperglycemia in the alteration of the fetal insulin releasing mechanism. However, the data from the individual animals depicted in Table II (350 F, 255 F, $35 \mathrm{M}$ ) suggest that the hyperglycemia-hyperinsulinemia hypothesis of Pedersen may not be a sufficient explanation for the presence of fasting fetal hyperinsulinemia or augmented glucose mediated fetal insulin responses in these monkeys.

These conceptii from streptozotocin-treated pregnancies respond with elevations in plasma insulin levels to an infusion of a low concentration $(2 \mathrm{mg} / \mathrm{min})$ of amino acids whereas monkey fetuses and neonates from normal pregnancies (Table IV) and human premature infants (15) require a 10 -fold greater concentration of amino acids in the infusate for a similar response. These observations suggest that in the streptozotocin-treated pregnancies the fetal and neonatal pancreatic islets are more sensitive to the insulinogenic action of amino acids. Moreover, since elevations in the plasma concentrations of the insulinogenic amino acids valine, leucine, and isoleucine, do occur in spontaneous (27) and acquired (28) diabetes, the streptozotocin-induced diabetes-like state could result in an increased availability of these amino acids to the fetal blood pool $(29,30)$. Thus, fetal hyperinsulinemia could result from relatively augmented fetal plasma amino acid levels in the absence 
of fetal hyperglycemia. A similar independent regulation of pancreatic insulin secretion by the plasma amino acids has been postulated in human obesity (31). Lastly, fetal hyperglycemia and hyperaminoacidemia could also act synergistically as well as independently in enhancing fetal islet cell function (32). Definitive clarification of the role of hyperglycemia and hyperaminoacidemia, alone or in combination, will require the direct measurement of plasma amino acid in both fetal and maternal blood pools.

Similar to our observations in the normal control studies (1-3), fetal and neonatal plasma growth hormone concentrations were not consistently altered in the presence of hyperglycemia or hyperaminoacidemia in the streptozotocin-treated pregnancies. Nor were fetalneonatal differences identified in mean plasma growth hormone levels. The average base line growth hormone level in the treated fetuses was $8 \pm 2.8 \mathrm{ng} / \mathrm{ml}$ and the treated neonates, $9 \pm 2.2 \mathrm{ng} / \mathrm{ml}$. The mean of the fetal base line plasma growth hormone concentration in the streptozotocin-treated pregnancies is less than the base line mean plasma growth hormone levels $(16.0 \pm 1.4 \mathrm{ng} /$ $\mathrm{ml}$ ) observed in our normal controls $(P<0.005)$. The same direction of difference was observed in human cord blood when samples from normal pregnancy were compared to those from pregnancies complicated by diabetes mellitus (33). However, the disparity in sample size in our study (9 streptozotocin-treated pregnancies vs. 42 control pregnancies) confounds any specific interpretation. Further studies will be necessary to establish whether the fetal growth hormone-releasing mechanism is also altered in the presence of compromised maternal carbohydrate and insulin metabolism.

8 of the 29 gestations in animals treated with streptozotocin were complicated by second or third trimester deadborns. This fetal complication parallels that observed in human gestation complicated by diabetes mellitus when no special care is taken $(34,35)$. One of the more enigmatic problems which the present study also highlights is the apparent lack of any correlation between the extent or magnitude of the maternal metabolic alterations and fetal survival. Thus, the mean of the fasting maternal plasma glucose and insulin, the insulin, responses, and plasma glucose disappearance rates to intravenous glucose in the eight pregnancies associated with deadborns were not significantly different from the streptozotocin-treated animals from which liveborn offspring were obtained.

In further emphasis, when human gestation complicated by diabetes mellitus is managed under optimum conditions of therapy and control of the hyperglycemia, a substantial fetal loss rate is still encountered $(36,37)$. It appears that the fetal loss rate will not be further ameliorated until some decisive increase in our knowledge of the reasons why these babies die is obtained.
The animal model detailed in this paper may provide an experimental opportunity to improve further our understanding of the etiology of this refractory perinatal mortality.

\section{ACKNOWLEDGMENTS}

We are indebted to Mrs. Antoinette Schenk, Mrs. Rosemary Fox, and Mr. Cecil Gunter for their excellent technical assistance. This work was supported by the National Institutes of Health, Grant No. AM 14820, No. HD 01403, No. FR 05570, No. HD 03155, No. 5 RO1 AM14106, and National Foundation Grant No. CRBS-235.

\section{REFERENCES}

1. Mintz, D. H., R. A. Chez, and E. O. Horger III. 1969. Fetal insulin and growth hormone metabolism in the subhuman primate. J. Clin. Invest. 48: 176.

2. Chez, R. A., D. H. Mintz, E. O. Horger III, and D. L. Hutchinson. 1970. Factors affecting the response to insulin in the normal subhuman pregnant primate. $J$. Clin. Invest. 49: 1517.

3. Chez, R. A., D. H. Mintz, and D. L. Hutchinson. 1971. The effect of theophylline on glucagon and glucose mediated plasma insulin responses in the subhuman primate fetus and neonate. Metab. (Clin. Exp.). 20: 805.

4. Pedersen, J., B. Bojsen-Moller, and H. E. Poulsen. 1954. Blood sugar in newborn infants of diabetic mothers. Acta Endocrinol. 15: 33.

5. Osler, M. 1960. Body fat of newborn infants of diabetic mothers. Acta Endocrinol. 34: 277.

6. Cardell, B. S. 1953. Hypertrophy and hyperplasia of the pancreatic islets in newborn infants. J. Pathol. Bacteriol. 66: 335 .

7. Driscoll, S. G., K. Benirschke, and G. W. Curtis. 1960. Neonate deaths among infants of diabetic mothers: postmortem findings in ninety-five infants. Amer. J. Dis. Child. 100: 818.

8. Melichar, V. M., M. Novak, P. Hahn, and O. Koldovsky. 1964. Free fatty acid and glucose in the blood of various groups of newborns, preliminary report. Acta Paediat. Scand. 53: 343.

9. Baird, J. D., and J. W. Farguhar. 1962. The insulinsecreting capacity of the pancreas in the newborn infants of normal and diabetic women. Lancet. 1: 71.

10. Chen, C. H., P. A. J. Adam, D. E. Laskowski, M. L. McCann, and R. Schwartz. 1965. The plasma free fatty acid composition and blood glucose of normal and diabetic pregnant women and of their newborns. Pediatrics. 36: 843 .

11. Pitkin, R. M., and W. A. Reynolds. 1970. Diabetogenic effects of streptozotocin in Rhesus monkeys. Diabetes. 19: 85 .

12. Murray-Lyon, I. M., A. L. Eddleston, R. Williams, M. Brown, B. M. Hogbin, A. Bennett, J. C. Edwards, and K. W. Taylor. 1968. Treatment of multiple-hormoneproducing malignant islet cell tumor with streptozotocin. Lancet. 2: 895.

13. Sadoff, L. 1969. Effects of streptozotocin in a patient with islet cell carcinoma. Diabetes. 18: 675.

14. Dulin, W. E., and B. M. Wyse. 1969. Studies on the ability of compounds to block the diabetogenic activity of streptozotocin. Diabetes. 18: 459. 
15. Grasso, S., N. Saporito, A. Messina, and G. Reitano 1968. Serum insulin response to glucose and amino acids in the premature infant. Lancet. 2: 755.

16. Meyer, V., and E. Knobil. 1967. Growth hormone secretion in the unanesthetized Rhesus monkey in response to noxious stimuli. Endocrinology. 80: 163 .

17. Herbert, V., L. Kam-Seng, C. W. Gottlieb, and J. J. Bleicher. 1965. Coated charcoal immunoassay of insulin. J. Clin. Endocrinol. Metab. 25: 1375.

18. Drash, A., J. B. Field, L. Y. Gorces, F. M. Kenny, D. H. Mintz, and A. M. Vasquez. 1968. Endogenous insulin and growth hormone responses in children with newly diagnosed diabetes mellitus. Pediat. Res. 2: 94.

19. Satterthwaite, F. E. 1946. An approximate distribution of estimates of variance components. Biometrics. 2: 110.

20. van Wagenen, G., and H. R. Catchpole. 1956. Growth of the fetus and placenta of the monkey (Macaca mulatta). Amer. J. Phys. Anthropol. 23: 23.

21. Behrman, R. E., A. E. Seeds, F. C. Battaglia, A. E. Hellegers, and P. D. Bruns. 1964. The normal changes in mass and water content in fetal Rhesus monkey and placenta throughout gestation. Pediatrics. 65: 38 .

22. Jacobson, H. N., and W. F. Windle. 1960. Observations on mating, gestation, birth and postnatal development of Macaca mulatta. Biol. Neonatorum. 3: 105.

23. Fujikura, T., and W. H. Niemann. 1967. Birth weight, gestational age and type of delivery in Rhesus monkeys. Amer. J. Obstet. Gynecol. 97: 76.

24. Kerr, G. R., A. L. Kennan, H. A. Waisman, and J. R. Allen. 1969. Growth and development of the fetal Rhesus monkey. I. Physical growth. Growth. 33: 201.

25. Farquhar, J. W. 1959. The child of the diabetic woman. Arch. Dis. Childhood. $34: 76$.

26. Peel, J. H. 1955. Management of the pregnant diabetic. Brit. Med.J. 2: 870 .

27. Carlsten, A., B. Hallgren, R. Jagenburg, A. Svanborg, and L. Werkö. 1966. Amino acids and free fatty acids in plasma in diabetes. I. The effect of insulin on the arterial levels. Acta Med. Scand. 179: 361.

28. Ivy, J. H., M. Svec, and S. Freeman. 1951. Free plasma levels and urinary excretion of 18 amino acids in normal and diabetic dogs. Amer. J. Physiol. 167: 182.

29. Dancis, J. 1960. Placental function and fetal nutrition. In The Placenta and Fetal Membranes. C. A. Villee, editor. The Williams \& Wilkins Co., Baltimore. 85.

30. Kerr, G. R. 1967. Transplacental ratios of serum free amino acids during pregnancy in the rhesus monkey. In Amino Acid Metabolism and Genetic Variation. W. L. Nyhan, editor. McGraw-Hill Book Company, Inc., New York. 429.

31. Felig, P., E. Marliss, and G. Cahill. 1969. Plasma amino acid levels and insulin secretion in obesity. $N$. Engl. J. Med. 281: 811.

32. Floyd, J. C., Jr., S. S. Fajans, S. Pek, C. A. Thiffault, R. F. Knopf, and J. W. Conn. 1970. Synergistic effect of certain amino acids and glucose upon insulin secretion in man. Diabetes. 19: 109.

33. Kalkhoff, R., D. S. Schalch, J. L. Walker, P. Beck, D. Kipnis, and W. H. Daughaday. 1964. Diabetogenic factors associated with pregnancy. Trans. Ass. Amer. Physicians Philadelphia. 77: 270.

34. Henley, W. E. 1947. Diabetes and Pregnancy. N. Z. Med.J. 46: 386 .

35. Lawrence, R. D., and W. G. Oakley. 1942. Pregnancy and diabetes. Quart. J. Med. 2: 45.

36. Oakley, W. 1965. The treatment of pregnancy in diabetes mellitus. In $\mathrm{On}$ the Nature and Treatment of Diabetes. B. S. Leibel and G. A. Wrenshall, editors. Excerpta Medica Foundation, Publishers, Amsterdam. 673.

37. Brandstrup, E., M. Osler, and J. Pedersen. 1961. Perinatal mortality in diabetic pregnancy: the relationship to management during pregnancy and to foetal age and weight. Acta Endocrinol. 37: 434. 